\title{
THE MODERN TECHNOLOGY OF IRON AND STEEL PRODUCTION AND POSSIBLE WAYS OF THEIR DEVELOPMENT
}

\author{
Y. Gordon ${ }^{1}$, S. Kumar 1 , M. Freislich ${ }^{1}$, Y. Yaroshenko², N. Spirin ${ }^{2}$ \\ ${ }^{1}$ Hatch (Mississanga, Ontario, Canada) \\ ${ }^{2}$ Ural Federal University (Department «Thermal Physics and Computer Science \\ in Metallurgy», Ekaterinburg, Russia)
}

В изменяющейся мировой обстановке на рынке сырых материалов для черной металлургии разрабатывается ряд новых технологий по производству чугуна и стали, альтернативных существующим технологиям, которые способны обеспечить экономически устойчивую работу металлургических компаний. В дополнении к этому фокусируется внимание на экономии энергии и снижении выбросов парниковых газов в иелях решения важнейших вопросов охраны окружающей среды. Изменение состояния окружающей среды ставит новые проблемы перед металлургической промышленностью, потребляющей значительные энергетические и топливные ресурсы. Отрасль вынуждена сосредоточить свое внимание на сокращении всех видов энергии, что приведет и к снижению выгроса парниковых газов. Разработка альтернативных технологических процессов производства чугуна и стали способна обеспечить металлургическим компаниям экономически выгодную и устойчивую работу в производстве стали. Для оценки воздействий деятельности металлургических компаний на окружаюшую среду Инженерно-консалтинговой компанией ХАТЧ (HАТCH, Canada) были разработаны новые методики моделирования, позволяющие квалифицированно и качественно оценивать риски в потреблении энергии и выбросах $\mathrm{CO}_{2}$ в металлургической промышленности. Методика для анализа выбросов углеродсодержаших парниковых газов названа G-CAP тм (Зеленый Дом - Борьба с загрязнением воздуха углекисльм газом), а для анализа энергоэффективности En-МАРТМ (Планирование действий при управлении энергией). Оценка существующего положения в большинстве интегрированных заводов показала, что они располагают возможностями по экономии энергии и борьбы с загрязнением атмосферы парниковыми газами, лучшие из этих заводов исчерпали эти возможности даже при высоких ценах на квоты выбросов СО . $_{2}$ В этом контексте важно оценить те важные особенности альтернативных технологий получения чугуна и стали, которые разработаны к настоящему времени. Эта статья содержит сравнительную оценку энергоэффективности и выбросов ПГ для некоторых выббранных альтернативных технологий производства чугуна и стали, которые рассматриваются для их реализации. Для этого применены методики G-CAP тм и G-CAP тм , элементы которых были разработаны в компании НАТСН с основной целью количественной и квалификационной оценки потенциила экономии энергии и сокращения выбросов $\mathrm{CO}_{2}$ в металлургической промышленности.

Ключевые слова: доменная печь для производства чугуна, альтернативные технологии производства чугуна, чугун (PI), плавление, железо прямого восстановления (DRI), горячее брикетированное железо (HBI), нуггеты (гранулы), выбор технологий. 
In the changing global market scenario for raw materials for the steel industry, a number of novel iron- and steelmaking process technologies are being developed to provide the steel companies with economically-sustainable alternatives for iron-and steel-making. In addition, the steel industry is also focusing on reduction of energy consumption as well as green-house gas $(G H G)$ emissions to address the crucial subject of climate change. Climate change is presenting new risks to the highly energy-and carbon-intensive, iron and steel industry. The industry needs to focus on reduction of energy consumption as GHG emissions to address climate change. Development of alternate iron-and steelmaking process technologies can provide steel companies with economically-sustainable alternatives for steel production. For managing climate change risks, novel modelling tools have been developed by Hatch to quantify and qualify potential energy savings and $\mathrm{CO}_{2}$ abatement within the iron and steel industry. The tool developed for abatement of greenhouse gas carbon is called G-CAPTM (Green-House Gas Carbon Abatement Process) while that developed for improving energy efficiency is called En-MAPTM (Energy Management Action Planning). Evaluation of existing operations have shown that most integrated plants have GHG and energy abatement opportunities; on the other hand, the best-in-class plants may not have a lot of low-risk abatement opportunities left, even at high $\mathrm{CO}_{2}$ price. In this context, it is important to assess these critical issues for the alternate iron- and steelmaking technologies that have been developed. This paper presents a comparative evaluation of energy-efficiency and GHG emissions for some selected iron-and steelmaking technologies that are being considered for implementation. In this work, Hatch's G-CAP ${ }^{\mathrm{TM}}$ and En-MAP ${ }^{\mathrm{TM}}$ tools that were developed with the main objective of quantifying and qualifying the potential energy savings and $\mathrm{CO}_{2}$ abatement within the iron and steel industry, were employed in the evaluation conducted.

Keywords: blast furnace ironmaking, alternative ironmaking technology, melting, direct reduced iron (DRI), hot briquetted iron (HBI), nuggets, pig iron (PI), technology selection.

\section{Introduction}

The iron and steel industry continues to transform itself and evolve in the everchanging global market place - the raw material scenario is constantly changing with respect to quality and quantity (availability), there is stiff competition in both global and local markets, and there is increasing pressure to address global climate change issues, especially since the steel industry is highly energy- and carbon-intensive. There is growing importance of steel production in developing countries such as China and India - this means that the steel industry in these countries will play an important role in defining and shaping the future of the industry.

Climate change is expected to present new risks to the steel industry with respect to ensuring a sustainable business. Legislators are proposing to limit GHG emission by placing an implicit price on $\mathrm{CO}_{2}$ emission - market-based «cap and trade», carbon tax etc. In this scenario, it is important for the steel companies to reduce exposure to climate-related risks and at the same time, find business opportunities within these risks. Thus, there is a need to strategically manage the climate change risks; the key steps to strategically manage climate change risks are presented in Table 1 [1].

Some of the steps that are being taken by the steel industry to address climate change risks are presented as follows: 
Key Steps to Strategically Manage Climate Change Risks [1]

\begin{tabular}{|c|l|l|}
\hline No & \multicolumn{1}{|c|}{ Steps Involved } & \multicolumn{1}{c|}{ Details } \\
\hline $\mathbf{1}$ & $\begin{array}{l}\text { Quantify Your Carbon } \\
\text { "Footprint" }\end{array}$ & $\begin{array}{l}\text { Quantify the sources and sinks of CO2 within the business in order to } \\
\text { Commence the process of emissions management. }\end{array}$ \\
\hline $\mathbf{2}$ & $\begin{array}{l}\text { Assess your Carbon Related } \\
\text { Risks and Opportunities }\end{array}$ & $\begin{array}{l}\text { Review the impact or opportunity within the following risks: regulatory, } \\
\text { supply chain, product or technology, Litigation, Reputation and } \\
\text { physical. Understanding the risk is fundamental to managing the risk }\end{array}$ \\
\hline $\mathbf{3}$ & Adapt your Business & $\begin{array}{l}\text { Develop and implement activities to reduce energy consumption and } \\
\text { Carbon emissions. Identify how to seize new opportunities. }\end{array}$ \\
\hline $\mathbf{4}$ & Do it Better than Rivals & $\begin{array}{l}\text { Take the lead in reducing exposure to climate change risk and realising } \\
\text { opportunities. Promote success to the market and legislators. }\end{array}$ \\
\hline
\end{tabular}

- Expand usage of current Energy- and $\mathrm{CO}_{2}$-efficient technologies in steel plants to minimize GHG emissions and energy consumption.

- Develop novel iron - and steelmaking technological solutions to significantly reduce specific energy consumption and specific GHG emission.

- Optimize and maximize recycling of steel scrap.

- Maximize value of steel industry by-products (wastes); recycling of steel plant wastes.

- Facilitate use of new generation of steels to improve energy efficiency of steel-using products in partnership with customers.

For a given site (location), it is necessary to select the best alternate ironmaking / steelmaking process technology(ies). In the selection of the best-suited alternate iron-and steel making technologies for a given site, a two-step approach is adopted for delivering a good end-result [2]:

- The first step includes broad evaluation of all available site-specific information followed by short-listing of 2 to 3 potential process technologies based on risk analysis, simple pay back period calculation, as well as factored capital cost analysis and operating cost estimates. During this stage, a preset process of technical and economic analyses is applied to screen and filter all available technologies.

- The second step involves detailed financial analysis of the shortlisted process technologies, resulting in the final selection of the best-suited technology.

In the two-step selection process, market opportunities / weaknesses are also assessed to get an idea of expected steel demand, quality requirements, and price trends. On this basis, the appropriate (or the best) site-specific process technology is selected through a proper techno-economical evaluation of all potential technologies as well as considering the consolidated impact of technology, cost of production and transportation. The key evaluation metrics that are typically included in the evaluation and selection of process technology for a given site are presented in Table 2 [2].

Considering the significance of climate change risks for the highly energyand carbon-intensive steel industry, it is necessary to evaluate the environmental aspects when considering an alternate process technology for implementation. This paper presents the results of an analysis conducted to compare the Energy Efficiency as well as GHG emissions associated with the different process technologies that are relevant to the iron and steel industry. 
Key Evaluation Metrics for Techno-Economic Analysis [2]

\begin{tabular}{|c|c|}
\hline Parameters & Details of the Evaluation Metrics \\
\hline Market Analysis & Requirements of final steel product \\
\hline Raw Material & Raw material requirement, its quality and availability \\
\hline Fuel and Energy & Fuel requirement, types of fuels, availability, related quality \\
\hline $\begin{array}{l}\text { Process Technology } \\
\text { Analysis }\end{array}$ & $\begin{array}{l}\text { Principles of operation, concept flow-sheet, mass and energy balance, } \\
\text { consumption figures, scaling principles, technical (feasibility) issues }\end{array}$ \\
\hline Risk Analysis & $\begin{array}{l}\text { Risks assessment with respect to scaling, state of the development of the } \\
\text { technology, and complexity of operation }\end{array}$ \\
\hline Operating Cost & $\begin{array}{l}\text { Estimated operating cost based on key cost drivers and best practice } \\
\text { operating conditions }\end{array}$ \\
\hline Capital Cost & $\begin{array}{l}\text { Estimated complete capital cost including core process units as well as } \\
\text { infrastructure directly associated with process } \\
\text { technology }\end{array}$ \\
\hline Financial Analysis & $\begin{array}{l}\text { Detailed financial analysis including analyses of local tax and deprecia- } \\
\text { tion implications and analysis of sustainable maintenance - these as- } \\
\text { pects of project are evaluated utilizing an IRR / NPV estimate, based on } \\
\text { discounted cash flow analyses and analysis of project financing impact }\end{array}$ \\
\hline
\end{tabular}

\section{Process Modelling and Tools for Decision Support}

Modelling tools have been developed by Hatch to quantify potential energy savings and $\mathrm{CO}_{2}$ abatement within the iron and steel industry ${ }^{[3]}-$ the tool employed for abatement of greenhouse gas carbon is called G-CAP ${ }^{\mathrm{TM}}$ (Green-House Gas Carbon Abatement Process) while that employed for improving energy efficiency is called En-MAP ${ }^{\mathrm{TM}}$ (Energy Management Action Planning) [3]. These tools are based on formalized methodology for identifying, quantifying, and ranking the available GHG abatement / energy reduction opportunities in a steel plant, so that a holistic understanding of the magnitude and costs associated with the various reduction scenarios can be achieved. With the help of these tools, it has been possible to identify, with certainty, how much $\mathrm{CO}_{2}$ emission and Energy Consumption can be abated by a defined point in time and at what cost to business. The G-CAP ${ }^{\mathrm{TM}}$ tool also has advanced features that allows setting of the initial $\mathrm{CO}_{2}$ and energy reduction targets, negotiating the $\mathrm{CO}_{2}$ cap allocation and managing the emission reduction pathway into the future. While the findings of G-CAP ${ }^{\mathrm{TM}}$ and En-MAP ${ }^{\mathrm{TM}}$ are generally applicable across the entire industry sectors, it is important to note that the calculations need to be customized on a plant-by-plant basis, due to variations in plant equipment, raw materials, and operations. The key elements of these tools are outlined as follow [3]: level.

1. Create inventory of all emission sources and sinks at site/business boundary

2. Disaggregate inventory to operating unit level.

3. Accuracy audit of disaggregated inventory, implement data quality improvements.

4. Establish a comprehensive Energy / Mass balance for each unit.

5. Collate operational key performance indicators (KPI's). 
6. Identify Best-in-Similar-Class and Best Practice benchmarks.

7. Normalize units to benchmark conditions.

8. Identify abatement opportunities to compress the gap with the benchmark.

9. Expected Improvement with $\mathrm{CO}_{2}$ Abatement / Energy Reduction Technologies.

10. Risk filter and eliminate unacceptable opportunities.

11. Model remaining opportunities and eliminate competing alternatives/ suboptimal scenarios.

12. Develop operational cash cost (Opex), capital investment requirements (Capex), Abatement and lead time estimates for opportunities and generate MACC (Marginal Abatement Cost Curve) or MEEC (Marginal Energy Efficiency Curve).

13. Identify $\mathrm{CO}_{2}$ price scenarios.

14. Map abatement and capital trajectories from MACC over time.

15. Set targets based on abatement cost/permit price differential.

A sample MACC is presented for reference in Fig. 1. The MACC / MEEC allows a business to identify, with certainty, how much $\mathrm{CO}_{2}$ emission or energy consumption can be abated by a defined point in time and at what cost to the business. The MACC is a well-developed tool for setting the initial $\mathrm{CO}_{2}$ reduction targets, negotiating the $\mathrm{CO}_{2}$ cap allocation and managing emission reduction pathway into the future. The MACC is equally relevant to identification of energy reduction initiatives. For developing MEEC, a sample of which is presented in Fig. 2, calculation of abatement curve for energy reduction requires assessment of the basket of energy consumptions in a given steel plant.

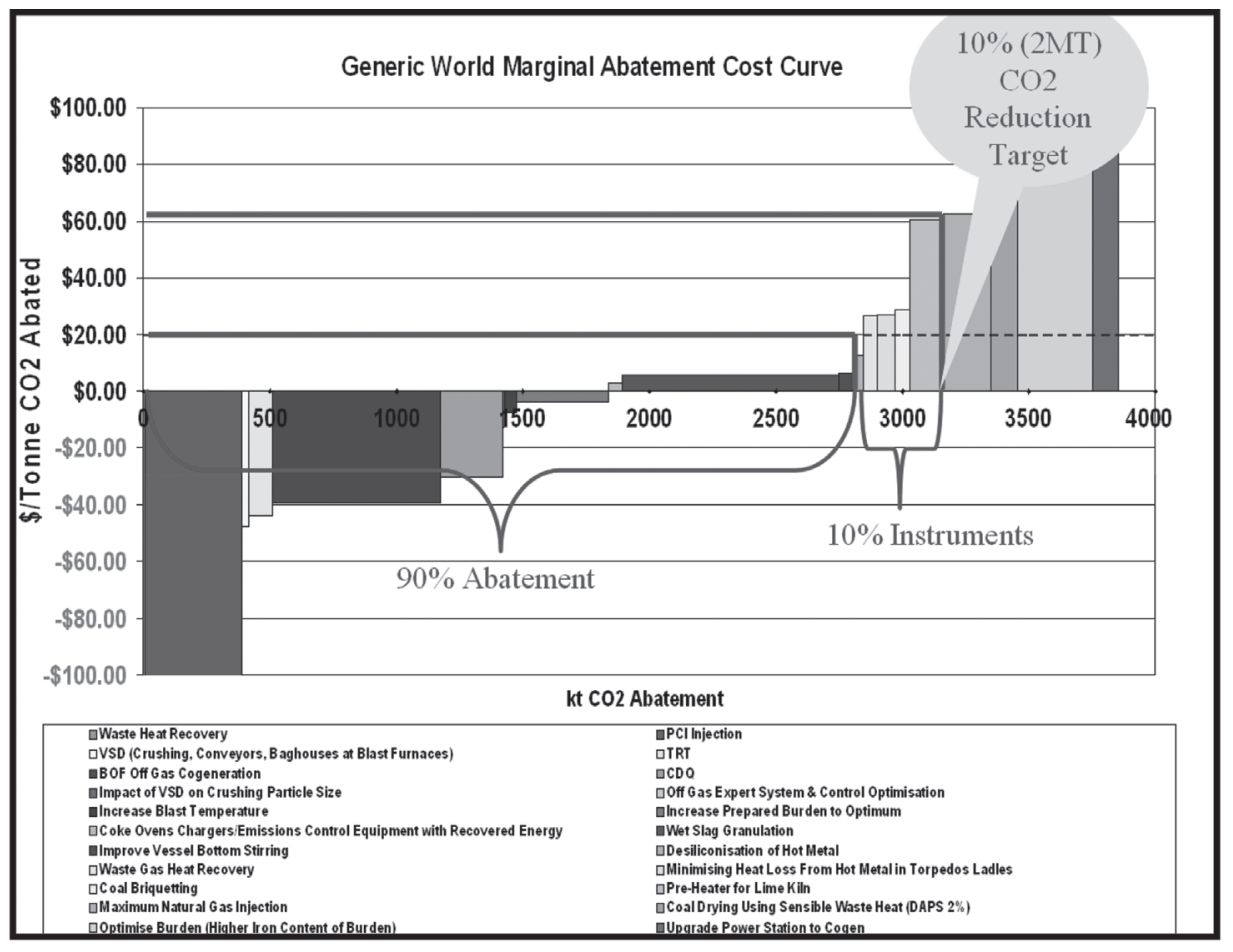

Fig. 1. Sample of Marginal Abatement Cost Curve (MACC) developed in a previous work [3] 


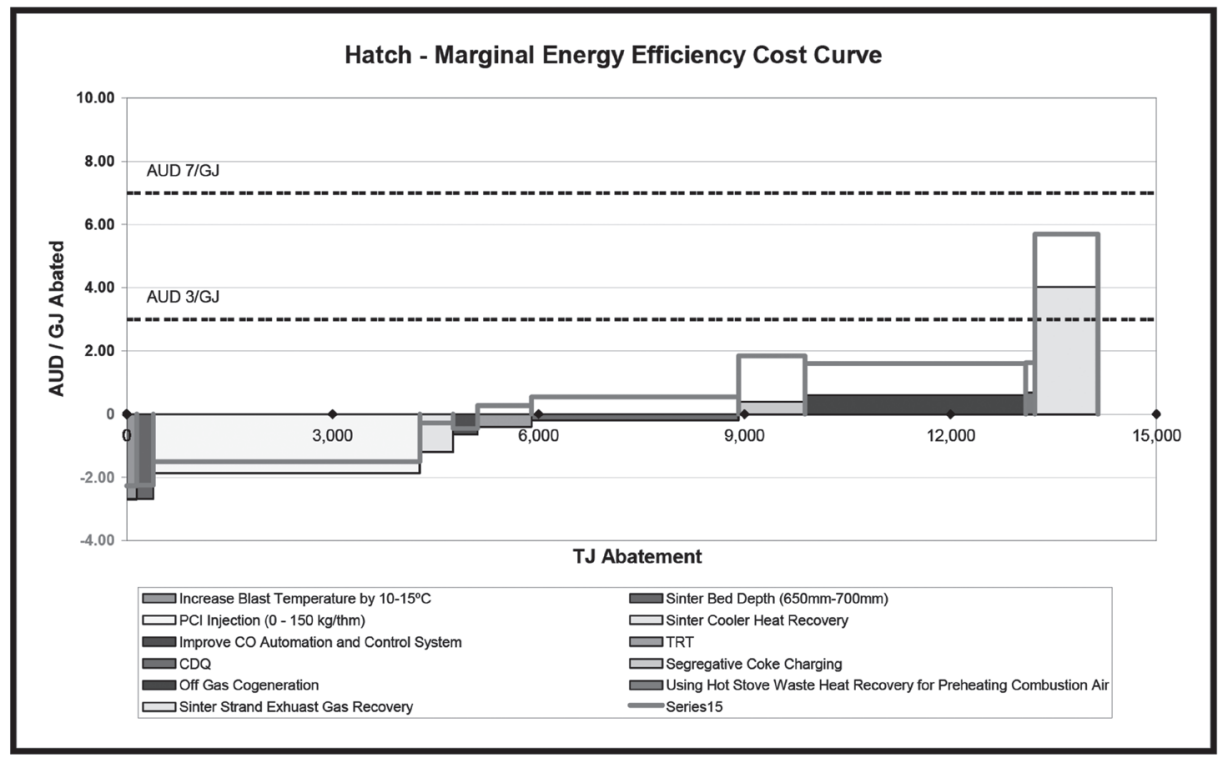

Fig. 2. Sample Marginal Energy Efficiency Curve (MEEC) developed in a previous work [3]

The G-CAP ${ }^{\mathrm{TM}}$ / En-MAP ${ }^{\mathrm{TM}}$ tools have been applied in several steel companies to assess energy efficiency as well as GHG emissions associated with both existing operations as well as new processes.

\section{Evaluation of GHG Emissions and Energy Efficiency}

A number of $\mathrm{CO}_{2}$ abatement / Energy Efficiency technologies are being considered by steel plants in the different areas of iron and steelmaking. The abatement opportunities were estimated for certain selected technologies / initiatives for a range of site conditions and constraints imposed at the sites with respect to implementation. The expected range of improvements estimated for certain $\mathrm{CO}_{2}$ abatement technologies / initiatives are presented in Table 3.

Range of Expected Improvements for some $\mathrm{CO}_{2}$ Abatement Initiatives

\begin{tabular}{|l|l|l|l|l|}
\hline & Plant & \multicolumn{2}{|l|}{ Savings in CO2 kg/t (Is) } & Constraint \\
\hline & & Low & High & \\
\hline Pulverised Coal Injection & BF & 25 & 66 & $\begin{array}{l}\text { Oxygen requirements, Energy } \\
\text { Balance }\end{array}$ \\
\hline Maximise natural gas injection & BF & 25 & 140 & As above \\
\hline Increase Blast Temperature & BF & 1.5 & 6 & Stove design \\
\hline Top Gas Recovery Turbine & BF & 10 & 40 & BF design, top temperature \\
\hline BOS off-gas recovery & BOS & 60 & 160 & $\begin{array}{l}\text { Off-gas system, plant } \\
\text { utilisation }\end{array}$ \\
\hline BOS waste heat boiler & BOS & 6.5 & 20 & Off-gas system \\
\hline Upgrade power station & ES & 20 & 45 & Operational security \\
\hline Sinter cooler waste heat recovery & SP & & 33 & $\begin{array}{l}\text { Corrosion, impact on sinter } \\
\text { quality }\end{array}$ \\
\hline Coke Dry Quenching & CO & 15 & 360 & $\begin{array}{l}\text { High maintenance costs, } \\
\text { offsets acceptable? }\end{array}$ \\
\hline Coal drying & CO & 16 & 60 & $\begin{array}{l}\text { Steam requirements, } \\
\text { maintenance }\end{array}$ \\
\hline
\end{tabular}


In addition to $\mathrm{CO}_{2}$ abatement / energy efficiency technologies / initiatives that are being implemented by steel companies, there are a number of alternate ironmaking process technologies that are provide valuable options to steel companies in dealing with the current issues. While the conventional blast furnace ironmaking process is still widely implemented, a number of these alternate ironmaking processes are being considered for implementation. Current status of some selected ironmaking process technologies are summarized in Table $4^{[2]}$.

Table 4

Current Status of Selected Ironmaking Technologies [2, 4-7]

\begin{tabular}{|c|c|}
\hline $\begin{array}{c}\text { Ironmaking Process } \\
\text { Technologies }\end{array}$ & Current Status \\
\hline Blast Furnace Process & $\begin{array}{l}\text { Most proven ironmaking technology with more than } 1,000 \text { installations } \\
\text { in the world. Capacity of blast furnace ranges from } 300,000 \text { to } 4,400,000 \\
\text { tpy of hot metal/pig iron }\end{array}$ \\
\hline COREX $^{\circledR}$ Process & $\begin{array}{l}\text { Capacity range from } 800,000 \text { to } 1,500,000 \text { tpy } 6 \text { installations in the } \\
\text { world; hot metal, pig iron }\end{array}$ \\
\hline Finex $^{\circledR}$ Process & $\begin{array}{l}\text { One plant in operation at Posco, South Korea with } 1,500,000 \text { tpy hot } \\
\text { metal capacity. }\end{array}$ \\
\hline $\begin{array}{l}\text { Gas Based DRI } \\
\text { Technologies } \\
\left(\text { Midrex }^{\mathbb{B}} \text { and HYL }{ }^{\circledR}\right)\end{array}$ & Numerous installations exist in the world up to $1,900,000$ tpy DRI \\
\hline $\begin{array}{l}\text { Coal Based DRI } \\
\text { Technologies } \\
\left(\text { Midrex }^{\circledR} \text { and } \mathrm{HYL}^{\circledR}\right)\end{array}$ & $\begin{array}{l}\text { Only one prototype operating - utilizing a reducing gas with similar } \\
\text { composition to the proposed synthetic gas from coal gasification - at } \\
\text { Saldana Steel (ArcelorMittal), South Africa, Midrex }{ }^{\circledR} \text { Megamodule. } \\
\text { This plant uses reducing gas produced in a Corex }{ }^{\circledR} \text { melter-gasifier } \\
\text { One plant is in operation and } 2 \text { more are in construction capacity up to } \\
1,900,000 \text { tpy }\end{array}$ \\
\hline $\begin{array}{l}\text { Rotary Kiln/ Smelter } \\
\text { Combination }\end{array}$ & $\begin{array}{l}\text { Several industrial installations in the world. Examples include New } \\
\text { Zealand Steel and Highveld (South Africa) }\end{array}$ \\
\hline $\begin{array}{l}\text { Rotary Hearth/Smelter } \\
\text { Combination }\end{array}$ & $\begin{array}{l}\text { Several installations in the world. Examples include Iron Dynamics } \\
\text { (Indiana, USA) and Inmetco (USA). Three rotary hearth furnaces are in } \\
\text { operation in Japan for waste treatment }\end{array}$ \\
\hline ITmk3 ${ }^{\circledR}$ Process & $\begin{array}{l}\text { The first industrial ITmk } 3 \circledR \text { process plant is in commissioning stage } \\
\text { and is expected to start routine operation in the summer of } 2011 \text {. Two } \\
\text { other plants are in the engineering and construction stages in USA and } \\
\text { Kazakhstan. Capacity - 500,000 (nugget) tpy }\end{array}$ \\
\hline Tecnored ${ }^{\circledR}$ Process & $\begin{array}{l}\text { Tecnored }{ }^{\circledR} \text { Process is currently at demonstration plant stage (in Brazil) } \\
\text { The plant has an annual design capacity of } 300,000 \text { tpy; not yet proven } \\
\text { on an industrial scale }\end{array}$ \\
\hline HIsmelt $^{\circledR}$ Process & $\begin{array}{l}\text { The first and the only HIsmelt }{ }^{\circledR} \text { process industrial plant in Kwinana, } \\
\text { Western Australia has been at ramp-up stage over the past several } \\
\text { years; not yet proven on an industrial scale }\end{array}$ \\
\hline Romelt $^{\circledR}$ Process & $\begin{array}{l}\text { First industrial Romelt } ₫ \text { plant (in Burma) is currently being constructed } \\
\text { and is expected to have a design annual capacity of } 200,000 \text { tpy; not yet } \\
\text { proven on an industrial scale }\end{array}$ \\
\hline
\end{tabular}




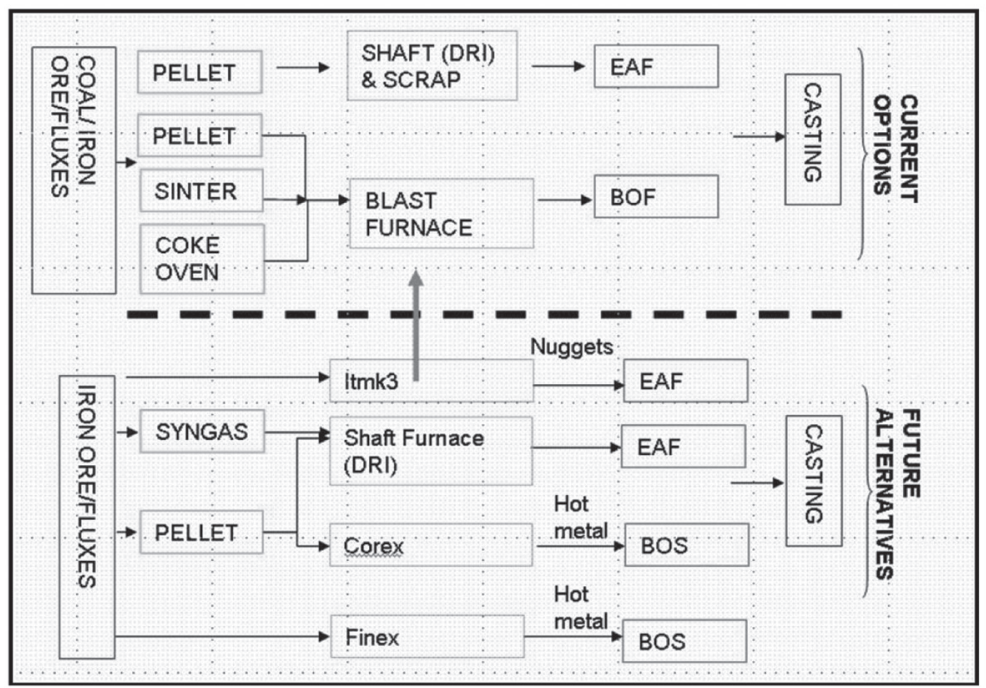

Fig. 3. Current options and future alternatives for iron and steel production

Fig. 3 presents some examples of future alternatives using the new ironmaking processes as well as the current options. Coal gasification technology allows usage of low-grade coal to produce a synthetic gas for DRI production; this option is especially useful in countries such as India where coal is available in plenty and there is limited natural gas availability.

In this work, the Energy Intensity (GJ/t) figures were estimated considering consumption and energy factors at the various stages of iron and steel productionthis includes all Direct Emission Sources (e.g. coal, natural gas, heavy and light oil, etc.) as well as all Upstream Emission Sources (e.g. purchased electricity, oxygen, nitrogen, steam, coke, fluxes, etc.). Credits for Energy Sources that are produced within the steel plant and sold/transferred outside the plant boundaries (e.g. tar, slag, electricity), are subtracted.

The results of the analysis are presented in Table 5 (in terms of GJ / $t$ of iron product, DRI or hot metal) and Table 6 (in terms of GJ / t of hot rolled product). It should be noted that end-product of these ironmaking technologies can be liquid hot metal, DRI or nuggets. The end product of rotary hearth and rotary kilns is DRI; but in the case of smelter option, the DRI is smelted and the final product is liquid hot metal (similar to that obtained from blast furnace).

The estimated energy intensity figures of Blast Furnace route compares well with those newer process technologies that have been widely adopted (such as Corex, Gas-based DRI - Midrex and Hyl). Only two developing ironmaking technologies, namely Romelt and Technored, have a superior energy intensity footprint as compared to the current processes namely Blast Furnace, Corex and Gas-based DRI processes.

$\mathrm{CO}_{2}$ emissions were also estimated for the various process technologies. The results are presented in Table 7 (in terms of $\mathrm{t} \mathrm{CO}_{2}$ per t of iron product, either liquid

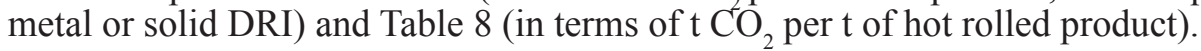


Estimated Energy Intensity for Process Technologies

Table 5 in terms of GJ per $\mathbf{t}$ Iron Product

\begin{tabular}{|l|l|}
\hline $\begin{array}{l}\text { Energy Intensity } \\
\text { (GJ } / \text { t Iron Product) }\end{array}$ & Process Technologies \\
\hline$<15.0$ & $\begin{array}{l}\text { Gas-based DRI (Midrex and HyL); } \\
\text { Romelt }\end{array}$ \\
\hline$>\mathbf{1 5 . 0}$ to 17.5 & $\begin{array}{l}\text { Itmk3; } \\
\text { Coal-based DRI (Midrex and Hy); } \\
\text { BlastFurnace }\end{array}$ \\
\hline$>17.5$ to $\mathbf{2 0 . 0}$ & $\begin{array}{l}\text { Corex with Power Generation; } \\
\text { Hismelt; }\end{array}$ \\
\hline $\mathbf{2 0 . 0}$ to $\mathbf{2 2 . 5}$ & $\begin{array}{l}\text { Corex with DRI Production; } \\
\text { Technored } \\
\text { Finex }\end{array}$ \\
\hline $\mathbf{2 2 . 5}$ to $\mathbf{2 5 . 0}$ & Rotary Hearth with Smelter \\
\hline $\mathbf{2 5 . 0}$ & Rotary Kiln with Smelter \\
\hline
\end{tabular}

Estimated Energy Intensity for Process Technologies in terms of GJ per t Hot Rolled Product

\begin{tabular}{|l|l|}
\hline $\begin{array}{l}\text { Energy Intensity } \\
\text { (GJ } / \text { t Hot Rolled Product) }\end{array}$ & Process Technologies \\
\hline$<\mathbf{2 0 . 0}$ & $\begin{array}{l}\text { Romelt } \\
\text { Technored }\end{array}$ \\
\hline $\mathbf{2 0 . 0}$ to $\mathbf{2 2 . 5}$ & $\begin{array}{l}\text { Gas-based DRI (Midrex and HyL); } \\
\text { Corex with Power Generation } \\
\text { Blast Furnace }\end{array}$ \\
\hline $\mathbf{2 2 . 5}$ to $\mathbf{2 5 . 0}$ & $\begin{array}{l}\text { Hismelt } \\
\text { timk3 }\end{array}$ \\
\hline $\mathbf{2 5 . 0}$ to $\mathbf{2 7 . 5}$ & $\begin{array}{l}\text { Finex } \\
\text { Coal-based DRI }\end{array}$ \\
\hline $\mathbf{2 7 . 5}$ to $\mathbf{3 0 . 0}$ & $\begin{array}{l}\text { Corex with DRI Production; } \\
\text { Rotary Kill with Smelter }\end{array}$ \\
\hline $\mathbf{3 0 . 0}$ & Rotary Kiln with Smelter \\
\hline
\end{tabular}

Estimated $\mathrm{CO}_{2}$ Emissions for Process Technologies

Table 7 in terms of $\mathbf{t} \mathrm{CO}_{2}$ per $\mathrm{t}$ Iron Product

\begin{tabular}{|l|l|}
\hline $\begin{array}{l}\mathrm{CO}_{2} \text { Emission } \\
(\mathrm{t} \mathrm{CO} / \mathrm{t} \text { Iron product) }\end{array}$ & Process Technologies \\
\hline$<1.00$ & $\begin{array}{l}\text { Gas-based DRI (Midrex and HyL); } \\
\text { Romelt }\end{array}$ \\
\hline$>1.00$ to 1.25 & $\begin{array}{l}\text { Corex with Power Generation; } \\
\text { Itmk3; }\end{array}$ \\
\hline$>1.25$ to 1.50 & $\begin{array}{l}\text { Blast Furnace; } \\
\text { Technored }\end{array}$ \\
\hline$>1.50$ to 1.75 & $\begin{array}{l}\text { Coal-based DRI (Midrex and HyL); } \\
\text { Hismelt }\end{array}$ \\
\hline$>1.75$ to 2.00 & $\begin{array}{l}\text { Finex; } \\
\text { Rotary Hearth with Smelter; } \\
\text { Corex with DRI Production }\end{array}$ \\
\hline$>2.00$ & Rotary Kiln with Smelter \\
\hline
\end{tabular}

Estimated $\mathrm{CO}_{2}$ Emissions in terms of $\mathrm{t} \mathrm{CO}_{2}$ per $\mathrm{t}$ of Hot Rolled Product

\begin{tabular}{|c|c|}
\hline $\begin{array}{l}\mathrm{CO}_{2} \text { Emission } \\
\text { ( } \mathrm{CO}_{2} / \mathrm{t} \text { Hot Rolled Product) }\end{array}$ & Process Technologies \\
\hline$<1.50$ & $\begin{array}{l}\text { Romelt } \\
\text { Technored }\end{array}$ \\
\hline$>1.50$ to 2.00 & $\begin{array}{l}\text { Gas-based DRI (Midrex and HyL): } \\
\text { Corex with Power Generation } \\
\text { Blast Furnace } \\
\end{array}$ \\
\hline$>2.00$ to 2.50 & $\begin{array}{l}\text { Itmk3 } \\
\text { Hismelt }\end{array}$ \\
\hline$>2.50$ to 3.00 & $\begin{array}{l}\text { Finex, } \\
\text { Rotary Hearth with Smelter; } \\
\text { Coal-based DRI } \\
\text { Corex with DRI Production }\end{array}$ \\
\hline$>3.00$ & Rotary Kiln with Smelter \\
\hline
\end{tabular}


On the basis of estimated $\mathrm{CO}_{2}$ emissions, it is noted that Romelt and Technored processes have a better $\mathrm{CO}_{2}$ footprint as compared to the conventional blast furnace route. In contrast to the newer process technologies ( such as $\operatorname{Corex}^{\circledR}$, Midrex ${ }^{\circledR}$ and $\mathrm{HyL}^{\circledR}$ ) that are widely adopted in the industry, the performance of conventional blast furnace ironmaking route is found to be comparable. On the other hand, performance of other developing technologies including Itmk3 and HiSmelt are found to be adverse as compared to Blast Furnace and the other technologies $\left(\right.$ Corex $^{\circledR}$, Midrex $^{\circledR}$ and $\left.\mathrm{HyL}^{\circledR}\right)$. Although coal-based DRI process can be a viable option for many regions (such as India) with large coal-deposits, this is expected to have an adverse $\mathrm{CO}_{2}$ footprint. Similarly, rotary hearth and rotary kiln processes with smelter option, also have adverse $\mathrm{CO}_{2}$ footprint.

\section{Summary and Conclusions}

- Climate change is presenting new risks to the highly energy- and carbonintensive, iron and steel industry. The industry needs to focus on reduction of energy consumption as well as green-house gas (GHG) emissions to address climate change. Development of alternate iron- and steelmaking process technologies can provide steel companies with economically-sustainable alternatives for steel production.

- For managing climate change risks, novel modelling tools have been developed by Hatch to quantify and qualify potential energy savings and $\mathrm{CO}_{2}$ abatement within the iron and steel industry. The tool developed for abatement of greenhouse gas carbon is called G-CAP ${ }^{\mathrm{TM}}$ (Green-House Gas Carbon Abatement Process) while that developed for improving energy efficiency is called En-MAP ${ }^{\mathrm{TM}}$ (Energy Management Action Planning). Evaluation of existing operations have shown that most integrated plants have GHG and energy abatement opportunities; on the other hand, the best-in-class plants may not have a lot of low-risk abatement opportunities left, even at high $\mathrm{CO}_{2}$ price.

- The traditional blast-furnace integrated route will continue to be a major process technology in the global steel industry (since this is a mature technology with a long history of optimization). In addition, its performance can be improved with the incorporation of available energy-savings and $\mathrm{CO}_{2}$ abatement technologies.

- The $\mathrm{CO}_{2}$ footprint of the newer, widely-accepted processes including Corex and Gas-based DRI option (Midrex and HyL) is comparable to that of the conventional blast furnace ironmaking route. It was found that only two developing technologies (Romelt and Technored) have a superior $\mathrm{CO}_{2}$ footprint as compared to the process technologies in use today.

- There are no currently available alternate iron- and steel-making technologies which can provide a significant (for example, over $20 \%$ ) reduction in GHG emissions or energy reduction versus a best-in-class conventional blast furnace ironmaking process route. Carbon capture and sequestration (CCS) on Gas-Based DRI processes, has the potential to emerge as a future technology that can provide large reduction in GHG emissions. 


\section{References}

1. Lash J., Wellington F. Competitive Advantage on a Warming Planet; Harvard Business Review, March 2007.

2. Gordon Y., Freislich M., Els J. Ironmaking Technology Selection for Site Specific Conditions; AISTech 2010 Proceedings, Volume 1, P. 519-528.

3. Addressing Climate Change - A Novel Greenhouse Gas Carbon Abatement Process $(G-C A P$ TM) for the Iron and Steel Industry S. Kumar, M. Freislich, D. Mysko, L.A. Westfall, S. Bachenheimer. AISTech 2010 Proceedings, Volume 1, P. 227-248.

4. Gordon Y., Freislich M., Brown R. Selection of ironmaking technology for existing specific conditions of European part of Russian Federation. Proceedings of AISTech Conference, Atlanta, GA, USA. 2012.

5. Gordon Y., Howey C. Implementation of new alternative ironmaking technologies: Experience and risk, Presented at 17th CIS Metals Summit, Moscow, Russia. 2012.

6. Wheeler F., Twigge-Molecey C., McLean L. Managing the Risk of Implementing New Technologies. Presented at the 36th Mechanical Working and Steel Processing Conference. Baltimore, Maryland, USA. 1994.

7. Gordon Y. Role of an Engineering Consultancy in the Transformation of a Technology Idea to a Working Process Plant. Proceedings of AISTech Conference, Cleveland, OH, USA. 2015. 